Muhammad Sajjad,

Ph.D., COMSATS University Islamabad, Pakistan

Anam Riaz,

COMSATS University Islamabad, Pakistan

Orangzab,

Ph.D., COMSATS University Islamabad, Pakistan

Muhammad Chani,

Ph.D., COMSATS University Islamabad, Pakistan

Rai Hussain,

University of Okara, Pakistan

\title{
INNOVATIONS IN HUMAN RESOURCES MANAGEMENT: MEDIATING ROLE OF INTRINSIC MOTIVATION
}

Abstract. This study determines the impact of loneliness on creativity through a powerful and essential mediator of intrinsic motivation. The ability to motivate oneself leads towards the accomplishment of tasks and creative work. In recent years, workplace loneliness has become a more critical issue in both academic and practical debates. So, this study highlighted the significant cause of creativity which could help the organization to handle the problem of loneliness. The study assumes that when isolation at the workplace is high, employees are less approachable towards their tasks. So, their performance and creativity reduced. Because loneliness leads to stress, depression and anger, it reduces the creative skills of employees. To enhance creativity, lonely employees must be motivated to minimise their adverse outcomes. So, the research question arises: Does intrinsic motivation (IM) intervene in between the workplace loneliness (WL) and employees' creativity? This study is also significant because employees and employers' relations are the backbone of their respective organizations and directly affect the performance and growth of their respective organizations. A data collection survey method was held on employees of Banking Sector currently working in Vehari district of Pakistan. Sample space was the employees of Pakistani banks working on officer grades. There is a total of 124 bank branches in Vehari District of Pakistan. In these 124 branches, a total of 726 employees were working on managerial positions which were targeted for data collection. Simple random sampling technique was employed to collect the information from the respondents. Simple random sampling techniques were used to avoid from the busyness and undesirable unknown effects from the target population. Data were obtained from 400 banking officers. For data collection, validated and adapted questionnaires were used. Each variable of the survey was measured through a Likert scale of 5 points. For statistics evaluation, the statistical tools such as reliability of data, collinearity of data, the association of variable's, mediation and Regression were tested. For data reliability and validation, Statistical Package for Social Sciences (SPSS) was used while to measure the direct, indirect or mediation effect was measured through smart pls 3. Smart PLS3 is a landmark in latent variable modelling. It combines state of the art methods with an easy to use and inbuilt graphical user interface. Structural Equation Modeling (SEM) is utilized to quantify the power of essential philosophies with spotted data. Results showed Workplace Loneliness has a definite and meaningful relationship with employee's creativity. Results also supported the intervening role of Intrinsic motivation (IM) between the relationship Workplace Loneliness (WL) on Employees' creativity (EC). The study provides significant implications in literature and for practitioners who are interested in measuring the profound effect of loneliness on creativity. Hypotheses are tested through mediation and for mediation analysis through the most commonly used approach of baron and Kenny. From results, it is stated that workplace loneliness is predicting the intrinsic motivation and creativity. Intrinsic motivation is the mediator in the current study, which partially intermediates the relation of WL and EC. So, it can be stated that employees can only be creative and able to utilize their cognition abilities for creativity when they are socially isolated from other works. The findings authenticate all hypotheses and their correspondence between the workplace loneliness, creativity and intrinsic motivation. In a nutshell, intrinsic motivation is the crucial element for creativity because when employees are internally satisfied with their work, they become energized and motivated and perform their work in a creative way.

Keywords: employees creativity, intrinsic motivation, mediation analysis, structural equation modelling, workplace loneliness.

Cite as: Sajjad, M., Riaz, A., Orangzab, Chani M., \& Hussain, R. (2020). Innovations in Human Resources Management: Mediating Role of Intrinsic Motivation. Marketing and Management of Innovations, 1, 110120. http://doi.org/10.21272/mmi.2020.1-08 

Intrinsic Motivation

Introduction. Workplace loneliness is a hurting feeling stimulated due to the deficiency in the relationships in the environment of the workplace (Kos et al., 2014). Negativity in relationships at work and the incapability to correct this disparity can lead to feelings of workplace loneliness (Stoica et al., 2014) Loneliness at workplace lead towards poor organizational performance. The study of isolation at the workplace is critical because according to societal psychology and neuropsychological point of view loneliness is a sentiment that imitates a vital but also short-term humanoid motivational states, like appetite, thirstiness or discomfort. The obsolete commencement of loneliness results in sadness, nervousness or poor societal skills (Cacioppo and Patrick, 2008). To maintain the best relationship at the workplace for better performance is very important, and it is possible only with the help of loneliness investigation thoroughly.

Employee creativity is essential due to the altering situation and prospects of technological advancement at the macro level. Creativity discusses the expansion of beneficial ideas about product and service processes. It plays a significant role in organizational success to achieve modest advantages (Amabile, 1983). At work, Individual factors like emotional experiences are the interpreter of creativity (James et al., 2004) sometimes negative emotions also inhibit the creativity at the workplace (To et al., 2015). Workplace loneliness is such a significant issue which attracted much attention in recent years, which have a destructive effect on employees wellbeing and performance (Ayazlar and Guzel, 2014).

Motivation and creativity are considered complementary since the researches consider them as essential factors within the organization and for the advancement of organizational outcomes (Oriol et al., 2016). Self-determination hypothesis has been recognized by (Deci and Ryan, 2008) among extrinsic and intrinsic motivated people. As employed, Intrinsic motivation connects positively with organizational engagement (Ryan and Deci, 2009), corporate fulfilment (Lavigne et al., 2007) intrinsic interest (Vallerand et al., 2008), and delight (Gonzalez et al., 2012). Intrinsically motivated workers try to be more creative and to obtain information better, since they get busier in their tasks and ultimately given more time, space and zeal to their activities at the workplace (García, 2016).

When loneliness at the workplace is high, employees are less approachable towards their tasks. So, their performance and creativity reduced. Because isolation leads towards stress, depression and anger that reduces the creative skills of employees, to enhance creativity, lonely employees must be motivated to minimise their adverse outcomes. So, the research question arises: Does intrinsic motivation (IM) intervene in between the workplace loneliness (WL) and employees' creativity?

This study determines the impact of loneliness on creativity through a powerful and essential mediator of intrinsic motivation. The ability to motivate oneself lead towards the accomplishment of tasks and creative work. So, this study highlighted the significant cause of creativity which could help the organization to handle the problem of loneliness. The study also determines the relationship of isolation and its effect on creativity in a collectivist culture like Pakistan. In this particular region, there are hardly few studies on loneliness. This study is also significant because employees and employers relations are the backbone of their respective organizations and directly affect the performance and growth of their organization (Howell and Hall-Merenda, 1999). In the current study, employee's creativity considered as a reliant variable and its relation is determined with workplace loneliness through the intermediating effect of intrinsic motivation. The subsequent conceptual framework is formed along with supported hypotheses are given below.

The factors which lead an employee toward loneliness at the workplace are related to emotional and social issues. Individuals emphasize their emotions when they estimate an objective related to their circumstances (Schwarz, 1990). Gallo et al. (2019) considered innovative management tools for small and medium enterprises and concluded that TQM enhances competitiveness.

During the assessment information about evaluator's capabilities, the evidence around the situation is also required. In the result of evaluator information, negative emotions evaluate negative thoughts when 

Intrinsic Motivation

judgments are made. At that time, employees who feel loneliness at workplace evaluate negative aspects from their evaluation which are low self-esteem and low self-efficacy (Woo et al., 2012).

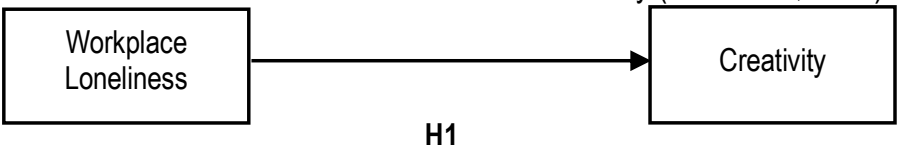

$\mathrm{H} 1$

Figure 1. Direct Relationship between IV and DV

Source: Proposed Relationship (Researchers Own Compilation).

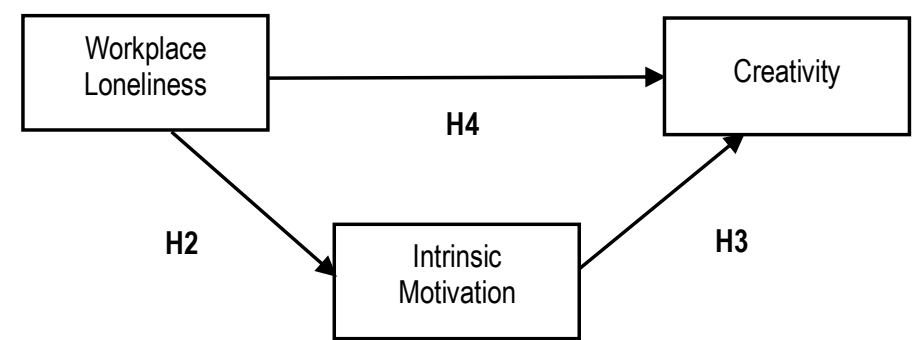

Figure 2. Indirect Relationship between IV and DV in the presence of Mediator

Source: Proposed Relationship (Researchers Own Compilation)

As per self-efficacy theory, due to little self-efficacy employees give lesser effort toward their creative tasks and fear of failure to perform creative activities increased (Tierney and Farmer, 2002). So, creativity decreased due to loneliness. From the above, it is hypothesized that:

H1: Workplace loneliness has a direct relationship with creativity.

Intrinsic motivation shapes to the point where an individual is self-determined and involved in or concerned with a task and deepened in that task in such a way to accomplish it at any stake (Utman, 1997). Intrinsic motivation has the most important and powerful influence on employees creativity (Eisenberger and Cameron, 1998). Other researches also find that IM is the point to which a worker is interested in completing the tasks at workplace and is enthused to involve in it for the sake of tasks itself (Paramitha and Indarti, 2014). Intrinsic motivation is considered as a primary motivational feature. Researchers also find that intrinsic motivation and creativity has a positive relationship in them (Grant and Berry, 2011). For creativity, it is necessary that employee should be interested in specific problems and find ways to solve these problems. Motivation supports to govern the consideration of employees and give solution to the experiential difficulties of innovative jobs (Woodman et al., 1993). So when they are intrinsically motivated than they become extra enthusiastic toward their work which increases their creative skills (Shalley et al., 2004).

Consequently, workplace loneliness can be related to intrinsic motivation and intrinsic motivation can be connected to employees" creativity. From the above, it can be stated that:

$\mathrm{H}$ 2: Workplace loneliness has a positive impact on intrinsic motivation.

H3: Intrinsic motivation has a positive impact on employees' creativity.

In addition to the direct relation between WL and EC, this study focuses on the mediating or intervening role of intrinsic motivation. According to the conservation of resource theory employees who are in lack of relations get into a situation of stress and become less motivated towards the completion of activities. By following this logic, it is expected that workplace loneliness is negatively related to IM. Second intrinsic motivation can have a positive influence on employee creativity. If employees are ready to take the risk of completing a difficult task, they become more creative. By following the high level of intrinsic motivation, employees are more confident with the available resources. In this condition, employees make more 

Intrinsic Motivation

efforts. Intrinsic motivation encourages employees toward creative activities. If the employees are less motivated, they are less innovative and afraid to take creative actions. (Zhao et al., 2014). After observing the above arguments, this study suggested that WL first blocks the development of intrinsic motivation and then diminishes their creativity. So, it can be said that IM intervenes in the relationship between workplace loneliness and employees' creativity and is stated as

$\mathrm{H} 4$ : Intrinsic motivation (IM) mediates the association between workplace loneliness (WL) and employees' creativity.

Methodology and Research Methods. Simple random sampling technique has been used for the study by employing the self-administered questionnaires. It is a quantitative, time-lagged and hypodeductive research. Data were collected from employees of the banking sector, Vehari, Pakistan. Respondents were contacted at their workplaces within their working hours while the anonymity of the participants was maintained.

There are 124 banks in District Vehari, Pakistan which includes four branches of Bank Al Habib with 36 officers level employees, National Bank of Pakistan (NBP) has ten offices with 54 officers, United Bank Limited (UBL) has 140 employees at officers' level, and 27 branches, Habib Bank Limited (HBL) has 18 offices with 49 officers. Muslim Commercial Bank (MCB) has 28 chapters and 140 officers working in it. Zarai Taraqiati Bank (ZTBL) consists of 8 sections with 82 officers, Bank of Punjab (BoP) has three branches with 21 officers. Allied Bank Limited (ABL) has 13 offices with 91 employees at officers' level. Fysal Bank has two branches with 24 officers. Askari Bank has three branches with 28 officers, 03 chapters of Meezan bank with 21 employees while Soneri bank has five offices with 40 employees.

The total number of employees at officer ranks which are employed in the Banking Sector of Vehari District is 726. The purpose of selecting this area of the population is that research in this aspect has never been conducted in Vehari District. Moreover, there is a large number of banks in this district, and organizational quitting is the foremost issue of banks, so we have selected the Banking Sector. The sample size of 400 was selected (Sajjad et al., 2019) with a random selection of respondents is used to avoid bias and other undesirable effects. It is the most suitable selection technique when the population is known.

The items of all the variables, i.e. workplace loneliness, intrinsic motivation and creativity have been measured through Likert-scale ranging from 1 to 5 points where one is being «Strongly Disagree» to 5 being «Strongly Agree». All the variables of this study have been adopted from well authenticated and valid sources. The detail of the adapted instruments with no. of items and verified source is given below in table 1.

Table 1. Instrument Basis, No. of Items and Reliabilities

\begin{tabular}{|c|c|c|c|}
\hline Variable & Source & No. of Items & Reliability \\
\hline Workplace Loneliness (IV) & (Wright et al., 2006) & 9 & 0.829 \\
\hline Intrinsic Motivation (Med) & (Tremblay et al., 2009). & 4 & 0.910 \\
\hline Employees Creativity (DV) & (George and Zhou, 2001) & 13 & 0.852 \\
\hline
\end{tabular}

Source: Wright et al., 2006, Tremblay et al., 2009, George and Zhou, 2001

Results. To analyze the collected data from the questionnaires, IBM SPSS (Statistical Package for the Social Sciences) was used. Data has been analyzed for investigating the coefficient of correlation, multicollinearity analysis, multiple regression and mediation analysis. Correlation analysis is used to estimate how the independent variable relates to the dependent variable. Regression analysis is used to scrutinize how much variation is in the independent variable. Mediation analysis was conducted as per (Preacher and Hayes, 2008) mediation analysis method. Smart PLS 3 (partial least square) is used for SEM analysis. It is a method of structural equation modelling. The significant component of PLS is its capacity to create certainty lapses for parameter evaluation and bootstrapped universal error (Byrne, 

Intrinsic Motivation

1994). Smart PLS3 is a landmark in latent variable modelling. It combines state of the art methods with an easy to use and in-built graphical user interface.

Structural Equation Modeling (SEM) is utilized to quantify the power of essential philosophies with spotted data (Lei and Wu, 2007). Arithmetically, it is the rearrangement of the Linear Modeling program, and these methods are also known as multiple linear regression modelling or identified as analysis of variance with variability. SEM is the more significant functions of GLM as compare to others. It also studies unintended interactions between the latent variables, which are stated by regular procedures. SEM is also used for a single surveyor for time series data analysis besides experimental and non-experimental data. Apart from this, Lei and Wu (2007) stated that the valuation of the underlying concept could be measured through factor analysis. In general, SEM contains an assessment of two different models. The first model is known as the measurement Model, while the second one is known as the path model. In the same sequence, the study has measured both the measurement and path models.

The primary purpose of SEM refers to examine either the assumed model or to determine the gathered data for estimation. This consistency is evaluated via model fit. To determine either theorized relations are tolerable or not the degree of model fit is used. There are some fundamental rules to analyze the proposed research model. First of all, we have to check the internal uniformity and dependability of the construct. For this purpose, we used smart PLS. Smart PLS-algorithm is utilized to check the reliability and validity of the observed variables. We assess the simple security from Cronbach alpha and composite reliability after running PLS-algorithm. Rendering to (Hair et al., 2014; Nunnally and Bernstein, 1994), if the calculated value of alpha and composite reliabilities are more significant than 0.70 , it shows the internal consistency and reliability of that construct is high. The results show that there is high reliability because the value of composite reliabilities for all constructs is more significant than 0.70 . The convergent validity (CV) is the degree in which calculated value is positively associated with the substitute measure of the similar concept. In table 2, there is a column of Average Variance Extracted (AVE) which shows the common calculated variance of the constructs and the indicators of the construct (Hair et al., 2014).

Table 2. Reliability Analysis

\begin{tabular}{|c|c|c|c|c|}
\hline & Cronbach Alpha & Rho-A & Composite reliability & Average Variance Extracted (AVE) \\
\hline WL & 0.822 & 0.829 & 0.864 & 0.417 \\
\hline CR & 0.907 & 0.910 & 0.921 & 0.484 \\
\hline IM & 0.833 & 0.852 & 0.889 & 0.667 \\
\hline
\end{tabular}

Source: Compilations from Field Data

To find out the absence of correlation between the measures of one construct to other construct discriminant validity is used (Ringle et al., 2010). Simply DV shows that there is no correlation between the measures of the construct. For this purpose, two approaches are used, which are first to find out the crossloading, and other is to find out the Farnell and larker criterion. For example, in cross-loadings, an external item loading on the related concept must be more significant as compared to all of its loadings for other constructs (Hair Jr et al., 2016). In table 3, the values of cross-loadings are showed.

Table 3. Farnell and larker criterion

\begin{tabular}{|c|c|c|c|}
\hline & CR & IM & WL \\
\hline CR & 0.689 & & \\
\hline IM & 0.654 & 0.817 & \\
\hline WL & 0.396 & 0.340 & 0.646 \\
\hline
\end{tabular}

Source: Compilations from Field Data 

Intrinsic Motivation

There are some bold values which are higher than the association with other constructs. So, we conclude that the results are satisfactory and meet the criterion of discriminant validity.

For the examination of discriminant validity second approach is to meet the Farnell and larker criterion. According to the (Fornell and Larcker, 1981) criterion, each constructs square root (which is Average variance extracted AVE) should be associated to bivariate correlations concerning all different variables (Gregoire and Fisher, 2006). When the square root value of the constructs are more significant than other constructs present in particular row and column, it is called discriminant validity (Hair Jr et al., 2016). In table 3 below, which exhibits the values of Fornell and Larker criterion demonstrate that the square root of workplace loneliness which is 0.646 is higher than other constructs intrinsic motivation which is 0.340 and creativity which is 0.396 . The results are satisfactory and according to the criterion.

Hetrotrait-Monotrait (HTMT) ratio is the third method used to examine the discriminant validity of the constructs. This criterion is used to create the discriminant validity among construct (Henseler et al., 2015). If the calculated answer of HTMT is less than 0.8 , it is considered as satisfactory and up to the mark. In table 4 , the values of HTMT are shown. These values are less than 0.8 ; hence it is proved that there is discriminant validity between constructs.

Table 4. Hetrotrait-Monotrait Ratio

\begin{tabular}{|c|c|c|c|}
\hline & CR & IM & WL \\
\hline CR & & & \\
\hline IM & 0.734 & & \\
\hline WL & 0.452 & 0.400 & \\
\hline
\end{tabular}

Source: Compilations from Field Data

Before testing of hypothesis, finding the collinearity between the constructs is the essential task. For the collinearity analysis tolerance value and VIF value is used. If the value of VIF is five or less than 5 , it explains that the issue of collinearity does not exist. On the other side, if the tolerance value is higher than 0.20 , it also proves no collinearity issue. In Table 5 below values of VIF and tolerance values are given tolerance values for all constructs are more significant than 0.20 and VIF values for all variables are less than five, then, it is proved that the collinearity issue does not exist.

Table 5. Assessment of Collinearity

\begin{tabular}{|l|c|c|c|}
\hline \multirow{2}{*}{ Model } & \multicolumn{2}{c|}{ Collinearity Statistics } \\
\cline { 2 - 4 } & Intrinsic motivation & .925 & VIF \\
\hline & Workplace loneliness & .925 & 1.081 \\
\cline { 2 - 4 } & & 1.081 \\
\hline
\end{tabular}

Source: Compilations from Field Data

When we find that there is no problem of collinearity than we can go for the testing of the hypothesis. For this purpose, bootstrapping is also used because bootstrapping delivers the values of T, P and path coefficients of the variables according to the model. In the current model, we notice the Influence of WL on EC with the intervening role of Intrinsic Motivation. This relationship is proved to be significant. In Table 6 , the results of hypotheses are given, which shows T-values are more significant than 1.96 and P-values are less than 0.5 while the significance is 0.000 for all hypotheses. So, based on the results, it is concluded that all hypotheses of the study are supported.

Hypotheses are tested through mediation and for mediation analysis most commonly used approach is baron and Kenny approach. Rendering to (Baron and Kenny, 1986) process of four steps is used. In the first step, the impact of predictor or changing the variable on the dependent variable has to be checked 
M. Sajjab, A. Riaz, Orangzab, M. Chani, \& R. Hussain. Innovations in Human Resources Management: Mediating Role of Intrinsic Motivation

without a mediator. In the current situation, the independent variable is workplace loneliness, and the dependent variable is creativity.

Table 6. Hypotheses Testing

\begin{tabular}{|c|c|c|c|c|c|}
\hline Hypothesis & Path coefficient & Standard Deviation & T-Value & P-Value & Decision \\
\hline IM $>$ - CR & 0.588 & 0.039 & 14.989 & 0.000 & Supported \\
\hline WL -> CR & 0.196 & 0.043 & 4.561 & 0.000 & Supported \\
\hline WL >> IM & 0.340 & 0.047 & 7.192 & 0.000 & Supported \\
\hline
\end{tabular}

Source: Compilations from Field Data

So, Table 7 shows the effect of WL on EC without the impact of the mediator. If the t values are higher than 1.96, it indicates that the relationship is significant. In the current scenario, which is shown in table 7 , T-value is more than 1.96 , which is 9.320 and P-value is 0.000 . So, we conclude that the association of the independent and dependent variable is significant by rendering that our first condition is fulfilled.

Table 7. Measurement of Direct Relationship

\begin{tabular}{|c|c|c|c|c|c|}
\hline & Original Sample & Sample Mean & Standard Deviation & T-Value & P-value \\
\hline WL $\rightarrow$ CR & 0.409 & 0.421 & 0.044 & 9.320 & 0.000 \\
\hline
\end{tabular}

Source: Compilations from Field Data

After authentication of independent and dependent variables which have a significant relationship, the next step is to testify the relationship of independent and dependent variable relationship in the presence of the mediator. If the strength of direct relationship changes after inclusion of mediator, it shows that the intervening variable has successfully mediated the relationship of the independent and dependent variable. In the current research, table 8 , indicates the relation of workplace loneliness, intrinsic motivation and creativity. T-value for this relationship is 6.229 , which is also greater than 1.96 , so we conclude that this relationship is also significant.

Table 8. Measurement of Indirect Relationship

\begin{tabular}{|c|c|c|c|c|c|}
\hline & Original Sample & Sample Mean & Standard Deviation & T-Value & P-Value \\
\hline WL $>$ > IM $>$ > CR & 0.200 & 0.204 & 0.032 & 6.229 & 0.000 \\
\hline
\end{tabular}

Source: Compilations from Field Data

When the effect of the mediator is confirmed, the next step is to check the size of its mediation, either its impact is full or partial. To find out the degree of mediation is also necessary. For finding the degree of mediation method of variance accounted for (VAF) is used. Finding an independent and dependent relationship is used. VAF is calculated as under:

$\mathrm{VAF}=$ Indirect Impact/ Total Impact

Indirect Impact = coefficient of predictor for mediating variable* mediation coefficient for the main variable under observation

Indirect effect $=\left(0.340^{*} 0.588\right)=0.200$, Direct effect $=0.409$

Total effect can be calculated by summing up the direct and indirect effect

Here the Total effect is equal to $0.409+0.200=0.609$

$\mathrm{VAF}=0.200 / 0.609=0.32$ Or $\mathrm{VAF}=32 \%$

For conclusion, if the value of VAF is between $20 \%$ to $80 \%$, it indicates that there is partial mediation of intrinsic mediation between workplace loneliness and creativity.

Figure 3 shows the direct relationship between WL and EC. There is a positive and significant relationship between the observed variable. The value of this relationship is 0.409 , which shows a positive and powerful direct correlation in between the workplace loneliness and creativity. The results are sufficient to run the mediation test for further analysis. 


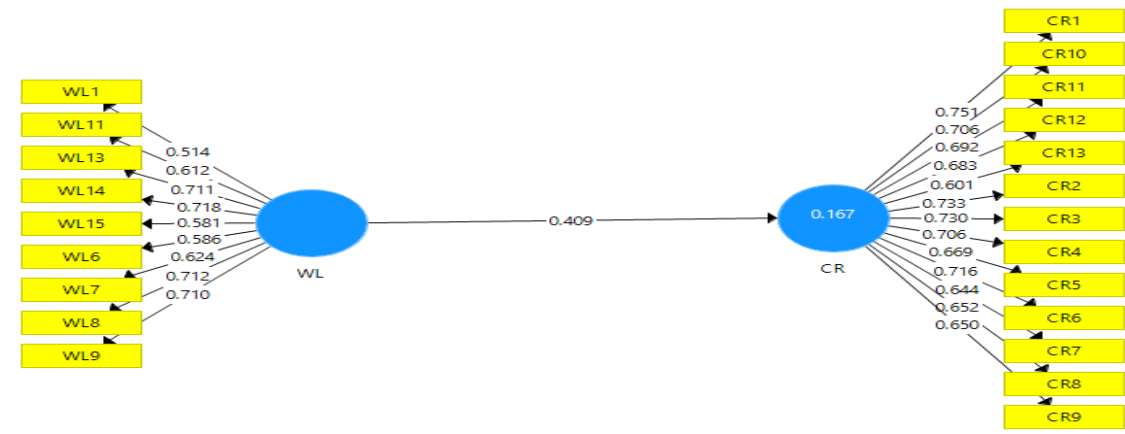

Figure 3. Direct Relationship without Mediation

Source: Compilations from Field Data

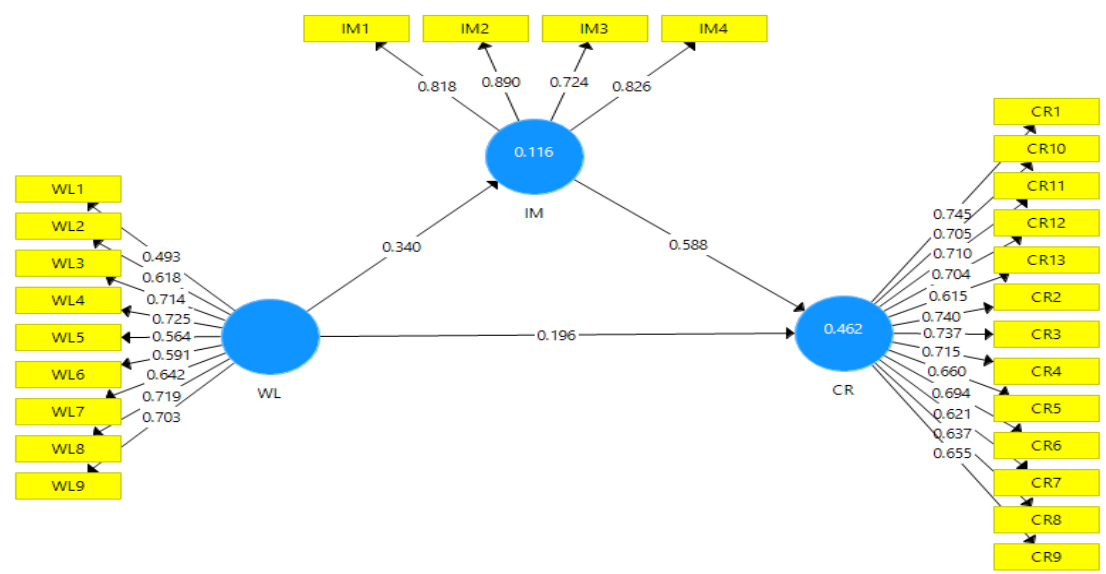

Figure 4. Structural Model in the Presence of Mediation

Source: Compilations from Field Data

Figure 4 above shows the effect of mediation i-e, the impact of IM between the WL and EC. Figure 4 and the results of VAF shows that the intrinsic motivation successfully mediates the relationship between WL and EC. It is further stated that the effect of mediation is partial. The cooperative and mutual impact of the predictor on EC is denoted by R2. Value of R2 in the direct model is 0.167 . It shows that $16.0 \%$ change in the workplace loneliness is ascertained and described by creativity. In the indirect model value of $\mathrm{R}^{2}$ is raised to 0.462 . It indicates that workplace loneliness and intrinsic motivation reciprocally defined and explain $46.2 \%$ alteration in creativity.

Conclusion. Purpose of the current study was to observe the influence of workplace loneliness (WL) on employees' creativity (EC) with the intervening role of intrinsic motivation (IM) in banks of District Vehari, Pakistan. From results, it is stated that workplace loneliness is predicting the inherent motivation and creativity. Intrinsic motivation is the mediator in the current study, which partially intermediates the relation of WL and EC. The results of this study authenticate all hypotheses and their correspondence between the workplace loneliness, creativity and intrinsic motivation.

Initially, it is indicated that WL has an optimistic impact on employees' creativity. WL can be expanded with the assumption that lonely employees are more creative, but banking employees face a lot of public dealings and routine tasks. Their busy schedules make them less creative. According to the present scenario, 

Intrinsic Motivation

they are just able to do everyday tasks and have to fulfil their assigned targets on time, and there is no room for creativity. Our study result showed that if bank employees have ample time apart from routine tasks and public dealings than they can be indulged in creativity. So, our results showed that bank employees could only be creative and able to utilize their cognition abilities for creativity when they are socially isolated from other works. Effects of the current study have reinforced the association between WL and EC. Researchers discovered that WL is wholly correlated with employee creativity. Result of the existing research also supported the relationship between intrinsic motivation and creativity. Outcomes of the current study, however, maintained the correlation of mediator in between the IM and EC. It is declared that there is a significant positive relationship exist between these variables. It is stated that when employees are intrinsically motivated, then they are more creative towards their task completion. They pay more attention to find out better ways of doing tasks and more focused on the overall quality of their work. Intrinsic motivation has a positive effect on creativity which also supported by (Steele et al., 2017). Conclusively, by including the intermediating variable, we originated that IM intervenes the connection of WL and employee's creativity. Result of this study shows that these two variables are positively associated with each other and has a significant impact with each other which also fulfils the fourth state of (Baron and Kenny, 1986). In the end, it is also proved that intrinsic motivation also plays a positive and significant relationship in the anticipated model. Intrinsic motivation is the central mediating instrument through which individual and relative factors affect creativity (Shalley et al., 2004). Thus, the administrators in the banking system should concentrate on human resource management and assist their staff in handling them gently and releasing the burden of work and giving time for likeness, self-discovery and spiritual elevation that will ultimately enhance the creativity of the employees (McKinney, 2006). Presents research come up with a new model, added it in the present literature and develops the new paths in the domain of management. The results showed that WL has positively anticipated the intrinsic motivation and creativity, and IM forecasts EC. In the end, IM intervenes the relation of WL and EC. More precisely loving and pleasant environment is essential for employees' creativity, which will improve through intrinsic motivation. Opinions of employees should be given the importance which motivates them to perform their work with solid devotion and results in the extraordinary performance of the employees (Wille et al., 2016). In a nutshell, intrinsic motivation is the crucial element for creativity because when employees are internally satisfied with their work, they become energized and motivated and creatively perform their job.

Author Contributions: Conceptualization, M. S., A. R.; methodology, O., A. R.; software, M. S., M. C.; validation, I. H., O.; formal analysis, M. C., O., M. S.; investigation, A. R.; resources, I. H., A. R.; data curation, A. R., I. H.; writing - original draft preparation, M. S., A. R.; writing - review and editing, M. S., M. C.; Supervision, M. S.

\section{References}

Amabile, T. M. (1983). The social psychology of creativity: A componential conceptualization. Journal of personality and social psychology, 45(2), 357-376. [Google Scholar] [CrossRef]

Ayazlar, G., \& Guzel, B. (2014). The effect of loneliness in the workplace on organizational commitment. Procedia-Social and Behavioral Sciences, 131, 319-325. [Google Scholar] [CrossRef]

Baron, R. M., \& Kenny, D. A. (1986). The moderator-mediator variable distinction in social psychological research: Conceptual, strategic, and statistical considerations. Journal of personality and social psychology, 51(6), 1173. [Google Scholar] []

Byrne, B. M. (1994). Structural equation modeling with EQS and EQS/Windows: Basic concepts, applications, and programming. Sage. [Google Scholar]

Cacioppo, J. T., \& Patrick, W. (2008). Loneliness: Human nature and the need for social connection. WW Norton and Company. [Google Scholar]

Deci, E. L., \& Ryan, R. M. (2008). Facilitating optimal motivation and psychological well-being across life's domains. Canadian Psychology/Psychologie canadienne, 491), 14. [Google Scholar] [CrossRef]

Draper, N. R., \& Smith, H. (1998). Applied regression analysis (Vol. 326): John Wiley and Sons. [Google Scholar] 
Eisenberger, R., \& Cameron, J. (1998). Reward, intrinsic interest, and creativity: New findings. [Google Scholar]

Fornell, C., \& Larcker, D. F. (1981). Structural equation models with unobservable variables and measurement error: Algebra and statistics. [Google Scholar] [CrossRef]

Gallo, P., Balogova, B., Tomcikova, L. \& Nemec, J. (2019). The impact of the innovative total quality management tool in small and medium-sized enterprises. Marketing and Management of Innovations, 4, 22-30. [Google Scholar] [CrossRef]

García, J. L. D. (2016). El nuevo escenario de las campañas digitales y su reflejo en unas elecciones regionales: el caso de Castilla y León, 2015. Paper presented at the La cibercampaña en Castilla y León: elecciones autonómicas 2015.

George, J. M., A \& Zhou, J. (2001). When openness to experience and conscientiousness are related to creative behavior: an interactional approach. Journal of applied psychology, 86(3), 513. [Google Scholar] [CrossRef]

Gonzalez, A., Paoloni, V., Donolo, D., \& Rinaudo, C. (2012). Motivational and emotional profiles in university undergraduates: A self-determination theory perspective. The Spanish journal of psychology, 15(3), 1069-1080. [Google Scholar] [CrossRef]

Grant, A. M., \& Berry, J. W. (2011). The necessity of others is the mother of invention: Intrinsic and prosocial motivations, perspective taking, and creativity. Academy of Management journal, 54(1), 73-96. [Google Scholar] [CrossRef]

Gregoire, Y., \& Fisher, R. J. (2006). The effects of relationship quality on customer retaliation. Marketing Letters, 171), 31-46. [Google Scholar] [CrossRef]

Hair Jr, J. F., Hult, G. T. M., Ringle, C., \& Sarstedt, M. (2014). A Primer on Partial Least Squares Structural Equation Modeling (PLSSEM). [Google Scholar]

Hair Jr, J. F., Hult, G. T. M., Ringle, C., and Sarstedt, M. (2016). A primer on partial least squares structural equation modeling (PLSSEM). Sage Publications. [Google Scholar]

Henseler, J., Ringle, C. M., and Sarstedt, M. (2015). A new criterion for assessing discriminant validity in variance-based structural equation modeling. Journal of the academy of marketing science, 43(1), 115-135. [Google Scholar] [CrossRef]

Howell, J. M., \& Hall-Merenda, K. E. (1999). The ties that bind: The impact of leader-member exchange, transformational and transactional leadership, and distance on predicting follower performance. Journal of applied psychology, 84(5), 680. [Google Scholar] [CrossRef]

James, K., Brodersen, M., \& Eisenberg, J. (2004). Workplace affect and workplace creativity: A review and preliminary model. Human Performance, 172), 169-194. [Google Scholar] [CrossRef]

Koc, F., Ozbek, V., \& Alniacik, E. (2014). The Moderating Role of Service Environment on the Effects of Firm Reputation and Perceived Service Quality on Consumer Trust: a Study in the Healthcare Industry. Journal of Global Strategic Management, 16, 111-120. [Google Scholar] [CrossRef]

Lavigne, G. L., Vallerand, R. J., \& Miquelon, P. (2007). A motivational model of persistence in science education: A self-determination theory approach. European Journal of Psychology of Education, 223), 351. [Google Scholar] [CrossRef]

Lei, P. W., \& Wu, Q. (2007). Introduction to structural equation modeling: Issues and practical considerations. Educational Measurement: issues and practice, 26(3), 33-43. [Google Scholar] [CrossRef]

McKinney, K. (2006). Initial evaluation of active minds: The stigma of mental illness and willingness of college students to seek professional help. (Doctoral dissertation, Colorado State University). [Google Scholar]

Nunnally, J. C., and Bernstein, I. (1994). Psychometric Theory (McGraw-Hill Series in Psychology)(Vol. 3): McGraw-Hill New York.

Oriol, X., Amutio, A., Mendoza, M., Da Costa, S., \& Miranda, R. (2016). Emotional creativity as predictor of intrinsic motivation and academic engagement in university students: the mediating role of positive emotions. Frontiers in psychology, 7, 1243. [Google Scholar] [CrossRef]

Paramitha, A., \& Indarti, N. (2014). Impact of the environment support on creativity: Assessing the mediating role of intrinsic motivation. Procedia-Social and Behavioral Sciences, 115, 102-114. [Google Scholar] [CrossRef]

Preacher, K. J., \& Hayes, A. F. (2008). Asymptotic and resampling strategies for assessing and comparing indirect effects in multiple mediator models. Behavior research methods, 403), 879-891. [Google Scholar] [CrossRef]

Ringle, C. M., Sarstedt, M., \& Mooi, E. A. (2010). Response-based segmentation using finite mixture partial least squares. In Data Mining (pp. 19-49). Springer, Boston, MA. [Google Scholar] [CrossRef]

Ryan, R. M., \& Deci, E. L. (2009). Promoting self-determined school engagement. Handbook of motivation at school, 171-195. [Google Scholar]

Sajjad, M., Chani, M. I., Tahir, M. S., \& Tariq, B. (2019). Local combats global: simulacrum of brand personality for tea brands Amazonia Investiga, 8(23), 203-212. [Google Scholar]

Schwarz, N. (1990). Feelings as information: Informational and motivational functions of affective states. The Guilford Press. [Google Scholar]

Shalley, C. E., Zhou, J., \& Oldham, G. R. (2004). The effects of personal and contextual characteristics on creativity: Where should we go from here? Journal of management, 3a6), 933-958. [Google Scholar] [CrossRef]

Steele, L. M., McIntosh, T., \& Higgs, C. (2017). Intrinsic motivation and creativity: opening up a black box. Handbook of Research on Leadership and Creativity.Edward Elgar Publishing. [Google Scholar] [CrossRef]

Stoica, M., Brate, A. T., Bucuta, M., \& Morar, S. (2014). The Association of Loneliness at the Workplace with Organizationa Variables. European Journal of Science and Theology, 10, 101-112. [Google Scholar]

Tierney, P., \& Farmer, S. M. (2002). Creative self-efficacy: Its potential antecedents and relationship to creative performance. Academy of Management journal, 456), 1137-1148. [Google Scholar] [CrossRef] 
M. Sajjab, A. Riaz, Orangzab, M. Chani, \& R. Hussain. Innovations in Human Resources Management: Mediating Role of Intrinsic Motivation

To, M. L., Fisher, C. D., \& Ashkanasy, N. M. (2015). Unleashing angst: Negative mood, learning goal orientation, psychological empowerment and creative behaviour. Human relations, 68(10), 1601-1622. [Google Scholar] [CrossRef]

Tremblay, M. A., Blanchard, C. M., Taylor, S., Pelletier, L. G., \& Villeneuve, M. (2009). Work Extrinsic and Intrinsic Motivation Scale: Its value for organizational psychology research. Canadian Journal of Behavioural Science/Revue canadienne des sciences du comportement, 41(4), 213. [Google Scholar]

Utman, C. H. (1997). Performance effects of motivational state: A meta-analysis. Personality and Social Psychology Review, 1(2), 170-182. [Google Scholar] [CrossRef]

Vallerand, R. J., Mageau, G. A., Elliot, A. J., Dumais, A., Demers, M. A., \& Rousseau, F. (2008). Passion and performance attainment in sport. Psychology of Sport and Exercise, 93), 373-392. [Google Scholar] [CrossRef]

Wille, M. M., Dirksen, A., Ashraf, H., Saghir, Z., Bach, K. S., Brodersen, J., . . \& Rasmussen, J. F. (2016). Results of the randomized Danish lung cancer screening trial with focus on high-risk profiling. American journal of respiratory and critical care medicine, 1935), 542551. [Google Scholar] [CrossRef]

Woo, P. C., Lau, S. K., Lam, C. S., Lau, C. C., Tsang, A. K., Lau, J. H., . . \& Zheng, B. J. (2012). Discovery of seven novel Mammalian and avian coronaviruses in the genus deltacoronavirus supports bat coronaviruses as the gene source of alphacoronavirus and betacoronavirus and avian coronaviruses as the gene source of gammacoronavirus and deltacoronavirus. Journal of virology, 86(7), 3995-4008. [Google Scholar] [CrossRef]

Woodman, R. W., Sawyer, J. E., \& Griffin, R. W. (1993). Toward a theory of organizational creativity. Academy of management review, 182), 293-321. [Google Scholar] [CrossRef]

Wright, S. L., Burt, C. D., \& Strongman, K. T. (2006). Loneliness in the workplace: Construct definition and scale development. [Google Scholar]

Zhao, H., Kessel, M., \& Kratzer, J. (2014). Supervisor-subordinate relationship, differentiation, and employee creativity: a selfcategorization perspective. The Journal of Creative Behavior, 483), 165-184. [Google Scholar] [CrossRef]

Мухаммад Саййад, Ph.D., Університет COMSATS в Ісламабаді (Пакистан);

Анам Ряз, Університет COMSATS в Ісламабаді (Пакистан);

Орангзаб, Ph.D., Університет COMSATS в Ісламабаді (Пакистан):

Мухаммад Чані, Ph.D., Університет COMSATS в Ісламабаді (Пакистан);

Раі Хуссейн, Ph.D., Університет Окара (Пакистан).

Інновації в управлінні людськими ресурсами: посередницька роль внутрішньої мотивації

У статті проаналізовано вплив відчуття самотності та внутрішньої мотивації працівників на рівень іх креативності. Авторами зазначено, що самомотивація сприяє підвищенню продуктивності та креативності працівників. У статті наголошено, що внутрішня мотивація працівника виступає медіатором між його креативністю та відчуттям самотності. В основу статті покпадено гіпотезу, що високий рівень відчуття самотності на робочому місці призводить до зниження продуктивності праці. У свою чергу, відчуття самотності породжує стрес, депресію та гнів, що є факторами зниження креативних здібностей працівників. Авторами зазначено, що підвищення рівня творчості працівників можливе за рахунок посилання його внутрішньої мотивації. Вихідні данні для дослідження сформовано на основі результатів опитування 400 працівників банківських відділень району Вехарі Пакистану. Аналіз результатів анкетування здійснено з використанням 5-ти бальної шкали Лайкерта. Рівень надійності, колінеарності та коінтеграції визначених параметрів здійснено з використанням методів статистичного аналізу. 3 метою забезпечення надійності та достовірності емпіричних результатів, авторами використано програмне забезпечення SPSS. Оцінювання прямого, непрямого та посередницького впливів визначених параметрів на результуючий показник здійснено з використанням Smart PLS3. Дане програмне забезпечення дозолило здійснити моделювання латентних змінних. Авторами зазначено, що систему структурних рівнянь використано для кількісного оцінювання сили впливу змінних на результуючий показник. Для перевірки генеральноі гіпотези щодо посередницької ролі внутрішньої мотивації працівників використано підхід Барона та Кенні. Отримані результати дослідження засвідчили, що відчуття самотності на робочому місці має статистично значущий вплив на креативність працівників. Авторами встановлено, що внутрішня мотивація відіграє посередницьку роль у взаємозв'язку між відчуттям самотності на робочому місці та креативністю працівників. Визначено, що працівники проявляють креативність, якщо вони мають вдосталь часу, непов'язаного із рутинними та посадовими завданнями. У зв'язку з цим у статті висунуто та емпірично підтверджено гіпотезу, що працівники проявляють творчість та використовують власні когнітивні здібності за умови ізольованостівід виконання інших оперативних справ. При цьому внутрішня мотивація виступає ключовим фактором упроявленні креативності на робочому місці, адже задоволені працівники є більш енергійними та мотивованими. Авторами наголошено, що результати дослідження мають практичне та теоретичне значення для проведення подальших досліджень з означеної проблематики.

Ключові слова: творчість працівників, внутрішня мотивація, посередницький аналіз, моделювання структурованих рівнянь, самотність на робочому місці.

Manuscript received: 11.09.2019

(c) The author(s) 2020. This article is published with open access at Sumy State University. 